\title{
Miranda
}

Revue pluridisciplinaire du monde anglophone /

Multidisciplinary peer-reviewed journal on the English-

speaking world

13 | 2016

Thomas Spence and his Legacy: Bicentennial

Perspectives

\section{A radical plan for the English language : Thomas Spence's "New Alphabet"}

Joan Beal

\section{OpenEdition}

\section{Journals}

\section{Electronic version}

URL: http://journals.openedition.org/miranda/9244

DOI: $10.4000 /$ miranda.9244

ISSN: 2108-6559

\section{Publisher}

Université Toulouse - Jean Jaurès

Electronic reference

Joan Beal, "A radical plan for the English language : Thomas Spence's "New Alphabet"', Miranda [Online], 13 | 2016, Online since 17 November 2016, connection on 16 February 2021. URL: http:// journals.openedition.org/miranda/9244 ; DOI: https://doi.org/10.4000/miranda.9244

This text was automatically generated on 16 February 2021

\section{(c) (1) $\odot$}

Miranda is licensed under a Creative Commons Attribution-NonCommercial-NoDerivatives 4.0 International License. 


\title{
A radical plan for the English language : Thomas Spence's "New Alphabet"
}

\author{
Joan Beal
}

\section{Introduction : Spence's plans}

1 In 1775, at the age of 25, Thomas Spence produced two publications which set out the agenda for his life's work: the printed version of his lecture to the Newcastle Philosophical Society, entitled Property in Land Every One's Right, and a dictionary, The Grand Repository of the English Language. The first of these introduced Spence's ideas on political and social reform, whilst the second was a vehicle for his plan of spelling reform. Until relatively recently, historians and biographers of Spence have tended to concentrate on his political ideas, paying much less attention to his views on language. The entry for Spence in the first edition of the Oxford Dictionary of National Biography (DNB) has only the following sentence on his orthographic reform :

He devised a new phonetic system explained in 'The Grand Repository of the English Language,' and endeavoured to popularise it in 'The Repository of Common Sense and Innocent Enjoyment,' sold in penny numbers 'at his school at the Keyside.' (Tedder 1897)

2 By omitting any reference to later works printed in Spence's reformed spelling, Tedder gives the impression that his proposed spelling reform was a youthful eccentricity abandoned once he engaged in serious political activism in London. Rudkin makes this point more explicitly when she suggests that "except for an occasional broadside, Spence made little use of his phonetics in London" (1927: 229). However, in the new edition of the DNB, Dickinson sets the record straight :

Spence continued to propagate his phonetic alphabet for the rest of his life. Several of his later radical works were printed in this alphabet as well as in standard English, and modern philologists now treat his efforts seriously. (2004) 

article (Beal 1999), and Anthea Fraser Shields (now Gupta) (1974) but credit for introducing Spence to the philological community must go to Abercrombie, who, in a paper first published in 1948, but later included in an important collection (1965) introduced Spence as a "forgotten phonetician", stating that "[I]n 1775 there appeared a dictionary in which the pronunciation was "parenthesized" [...] in a genuine, scientific, phonetic alphabet with seventeen new letters" (1948: 27). Spence's own view, expressed in The Important Trial of Thomas Spence was that both his plans were of equal importance :

When I first began to study, I found every art and science a perfect whole. Nothing was in anarchy but language and politics. But both of these I reduced to order, the one by a new alphabet, the other by a new Constitution. (1807)

4 This statement has been cited from the 1807 edition of Spence's account of his trial, but it is perhaps significant that an earlier edition of this pamphlet (1803) had been printed in his reformed spelling. Spence makes it clear that, even at the age of 25 , he had seen language and politics as equally 'anarchic' and equally in need of his radical reforms. The next section will consider why the English language was seen to be 'in anarchy' in the $18^{\text {th }}$ century, and how Spence's plans for reform addressed this issue.

\section{Language in anarchy}

Although complaints about the degeneration of the English language are far from unknown today, the $18^{\text {th }}$ century was a period in which concerns about regulating the language were particularly acute. The reasons for this, as outlined by Beal (2004: 93-101), are various, but can be summed up as follows. Firstly, there was a social or rather sociolinguistic motivation for this anxiety about what the correct form of English might be. Social mobility in this period created a literate and aspiring middling sort of people who were anxious to avoid the twin stigmas of vulgarity and provincialism. Secondly, there were educational reasons: in this period, there was increasing emphasis on the teaching of English in schools, especially in the dissenting academies. Teachers of English needed textbooks and, indeed, most of the grammars of English published in the $18^{\text {th }}$ century were written by teachers. There was also a political motivation in the perceived need for a single 'correct' form of English to unify the nation after the Act of Union (1707). Quite apart from these external factors, it could be argued that the English language had, by the $18^{\text {th }}$ century, simply reached the stage in the process of standardisation at which codification occurs. According to Haugen (1971), there are four processes involved in standardisation: selection of a language or dialect which will form the basis of the standard; codification, which involves the establishment of norms and the production of grammars, dictionaries, etc.; elaboration, ensuring that the standard can be used for a wide range of functions; and implementation, whereby various means are used to encourage use of the standard. There had been no standard variety of English for several centuries after the Norman Conquest, because French and Latin fulfilled the prestigious and official functions carried out by a standard. However, by 1500 a standard variety of English had been selected and by the beginning of the $18^{\text {th }}$ century this was well established and used for almost all purposes. (Latin was still being used, for instance, for some scientific 
publications, but this decreased as the century progressed). What was lacking at the beginning of the $18^{\text {th }}$ century was codification.

At the beginning of the century, Jonathan Swift, in a publication entitled A Proposal for Correcting, Improving and Ascertaining the English Tongue, made the following address to the Lord High Treasurer :

My LORD ; I do here, in the Name of all the Learned and Polite Persons of the Nation, complain to Your LORDSHIP, as First Minister, that our Language is extremely imperfect; that its daily Improvements are by no means in proportion to its daily Corruptions; that the Pretenders to polish and refine it, have chiefly multiplied Abuses and Absurdities; and, that in many Instances, it offends against every Part of Grammar. (1712: 8, 31)

7 Swift's proposed solution to what he clearly perceived as a crisis in the English Language was to set up an Academy like that in France, which would be responsible for 'correcting, improving and ascertaining' the language. The members of such an academy would, of course, be chosen from the 'learned and polite', in whose name Swift wrote the letter and, as demonstrated by Trapateau (2016), these two terms (learned and polite) were to become keywords in the metalinguistic comments on pronunciation provided by $18^{\text {th }}$-century authors such as John Walker. 'Ascertaining' had a very specific meaning in the context of Swift's letter, one which is, according to the Oxford English Dictionary (OED), obsolete today. The OED uses a citation from Swift's 1712 publication to illustrate the definition "[T]o make (a thing) certain, definite, or precise, by determining exactly its limits, extent, amount, position, etc. ; to decide, fix, settle, limit." (OED online) In other words, Swift was proposing that an Academy was needed in order to decide what the correct rules of English were, and then to fix these so that no further changes, or "corruptions" could occur. Of course, Swift's proposal for an academy was never implemented (Beal 2011 explains this failure). Instead, individuals took up the challenge, producing an unprecedented number of publications on the English language. Finegan appositely refers to "[T]he codification of English usage, not by an official academy but by a disparate band of independent entrepreneurs" (1998: 536) and the publication of English grammars, dictionaries and guides to 'correct' pronunciation was a thriving business especially in the later part of the $18^{\text {th }}$ century. As far as spelling and word usage are concerned, although other successful dictionaries were produced before and after this, the success and authority of Johnson's (1755) Dictionary of the English Language made him effectively a one-man academy. Grammars and grammarians, on the other hand, were legion : more than 200 grammars of English were published between 1750 and 1800 . Tieken-Boon van Ostede explicitly links this prolific production of grammars to the failure of proposals for an academy :

To a considerable extent this increase [in the production of grammars JCB] seems due to the fact that it finally became clear, after the death of Queen Anne in 1714, that England would never have an Academy [...]. One of the functions of such an Academy would have been to publish an authoritative grammar of English, alongside a dictionary [...]. When various individuals decided that they themselves could deal with what was commonly acknowledged to be an important desideratum, calls for the need of an Academy finally dwindled. (2008:3-4)

By the time Spence published the Grand Repository in 1775, the publication of English grammars was a lucrative business, and Newcastle was an important centre for educational publication. In particular, Alston (1965: I, 110-11) notes that, in the course of the $18^{\text {th }}$ century, more grammars of English were published in Newcastle than in any other anglophone city in the world except London. Most of these grammars were the 
work of the influential Newcastle-based teacher Anne Fisher, and Shields convincingly argues that the short grammar included in Spence's Grand Repository is essentially an abridged version of an earlier edition of Fisher's A Practical New Grammar (1787). Although we have no evidence of Spence and Fisher meeting, as a teacher in Newcastle, Spence could not have escaped her influence or that of her publications. Spence saw the importance of including rules of grammar in the Grand Repository, but was not an innovator in this sphere because his priorities were spelling and pronunciation, and the relationship between them. The next section will look at the rise of elocution guides and pronouncing dictionaries in the late $18^{\text {th }}$ century, and consider Spence's scheme for spelling reform in this context.

\section{Pronunciation and spelling}

9 Remarks about what kind of pronunciation had the most prestige and might constitute a suitable model for reformed spelling can be found from the $16^{\text {th }}$ century onwards, notably in the much-quoted reference of Puttenham to "the usuall speech of the Court and that of London and the shires lying about London within lx miles" (1589: 121). However, it is not until the second half of the $18^{\text {th }}$ century that acquiring a "standard" pronunciation becomes a priority for the upwardly-mobile, and that attempts to codify pronunciation are made. Charles Jones notes that "[B]etween 1750 and 1800 there is a sea-change in the way linguistic usage is perceived to relate to criteria such as social status and place of geographical origin" (2006: 117) and Holmberg refers to the $18^{\text {th }}$ century as the time when "the snob value of a good pronunciation began to be recognized" (1964: 20). The reasons for this are similar to those outlined in the previous section with reference to grammars, but where pronunciation was concerned, the scope for social embarrassment amongst the nouveaux riches and those aspiring to social mobility was much greater. Thomas Sheridan, whose Dissertation on the Causes of the Difficulties which Occur in Learning the English Tongue is widely quoted in the Grand Repository, makes the following statement:

Almost every county in England has its peculiar dialect. [...] One must have preference, this is the court dialect, as the court is the source of fashions of all kinds. All the other dialects, are sure marks, either of a provincial, rustic, pedantic or mechanical education, and therefore have some degree of disgrace annexed to them (1762: 29-30).

Although Spence does not include this extract in the Grand Repository, the title page of this work boasts that it has "the Peculiarity of having the most proper and agreeable Pronunciation of the alphabetic Words denoted in the most intelligible Manner by a New Alphabet". That he was acutely aware of the potential for what Sheridan termed 'disgrace' is made explicit in Spence's final publication The Giant-Killer, or Anti-Landlord, in which he asks :

Why should People be laughed at all their lives for betraying their vulgar education, when the Evil is so easily remedied. How ridiculous it is to hear People that can read saying Any Think - A Horange - Idear - Noar (1814).

However, Spence, unlike Sheridan and most other authors of guides to pronunciation, was not concerned with what we would now term 'accent reduction' in the sense of helping readers to lose regional accents. The specific features highlighted by Spence here are not peculiar to his own Newcastle dialect, nor, indeed to any specific regional variety. Instead, Spence focuses on three features which were to become national 
shibboleths of what was perceived as uneducated speech: the pronunciation of the velar nasal as $/ \mathrm{n} /$, or here as $/ \mathrm{yk} /$; the omission or unetymological addition of $/ \mathrm{h} /$; and intrusive $/ \mathrm{r} /$.

Indeed, as we shall see later (paragraphs $n^{\circ} 24-26$ ), Spence seems to have had a broad Northumbrian accent all his life. The 'ridiculous' pronunciations mentioned in the above quotation are not regional, but rather general nonstandard features which deviate from the spelling, and therefore make the speaker appear uneducated. The key phrase here is "people that can read" : if they had learned to read using Spence's alphabet, they would not have made these mistakes.

13 The Grand Repository is a pronouncing dictionary ; one of many produced in the second half of the $18^{\text {th }}$ century. The most successful of these were Thomas Sheridan's General Dictionary of the English Language (1780) and John Walker's Critical Pronouncing Dictionary (1791), but the earliest was James Buchanan's Linguae Britannicae Vera Pronunciatio (1757). All the other pronouncing dictionaries used systems involving diacritics and minimal respelling of words to give a guide to pronunciation without too much disruption to the conventional orthography. The received view of the relationship between spelling and pronunciation was that propounded by Johnson: "[F]or pronunciation, the best general rule is, to consider those as the most elegant speakers, who deviate least from the written words." (1755) Elsewhere in the preface to his Dictionary Johnson put forward the maxim that "for the law to be known is of more importance than for it to be right." (op. cit.) In other words, the conventional spelling, however irregular it seems, should be adhered to and even dictate pronunciation. By contrast, Spence sought to bring spelling into line with pronunciation. The following passage in the Supplement to the History of Robinson Crusoe (published in two editions, one of which was printed in Spence's alphabet) sounds like a satirical reference to Johnson's 'rule':

The language of the Lilliputians was irregular and difficult to be understood. [...] Spelling too was all confused being without Rule or Order, and the only sure Maxim they had laid down was, that all Words which could be sounded different Ways were to be written according to the hardest, harshest, longest and most unusual Sound. (1782: 58)

14 However, the immediate source of this 'maxim', which is also cited in the preface to the Grand Repository, is Sheridan's Dissertation (1762:9-10). Sheridan himself took the words from John Jones's Practical Phonography (1701: 6). Whereas Jones lays this down as a serious maxim, Sheridan cites it as an illustration of the 'difficulties' alluded to in the full title of his Dissertation and Spence uses it satirically to highlight the ludicrousness of the Lilliputians' system. The solution to this problem is the introduction of the Crusonean (i.e. Spence's) alphabet, which has the following consequences :

As they could now learn as much in a Month, as formerly in a Year, the very poorest soon acquired such Notions of Justice, and Equity, and of the Rights of Mankind, as rendered unsupportable, every species of Oppression. (1782)

In Spence's view, the introduction of a reformed and rational system of spelling was a means to an end: if poor people could learn to read, they would become politically informed and support his plan for the reform of society. The address to the reader at the end of the edition of Supplement to the History of Robinson Crusoe printed in Spence's alphabet further emphasises the intention to propagate knowledge by means of the new system of spelling: 
Therefore this Manner of Printing is calculated to render both the Teaching and the Learning of it a Pleasure ; and the well-inclined will think it only agreeable Pastime to instruct their own Children, Servants and Neighbours who will soon be qualified to teach others; and thus according to the Prophet will the Earth be filled with the Knowledge of the Lord, as the Waters cover the Sea. (1782:60, my transliteration)

The next section illustrates and evaluates Spence's 'New Alphabet' as set out in the Grand Repository.

\section{The 'New Alphabet'}

Spence first introduced his reformed spelling in the Grand Repository, where it is set out in the table reproduced here as figure 1 with the heading "The New Alphabet". Spence also provided the relevant symbols to be used in handwriting.

Figure 1

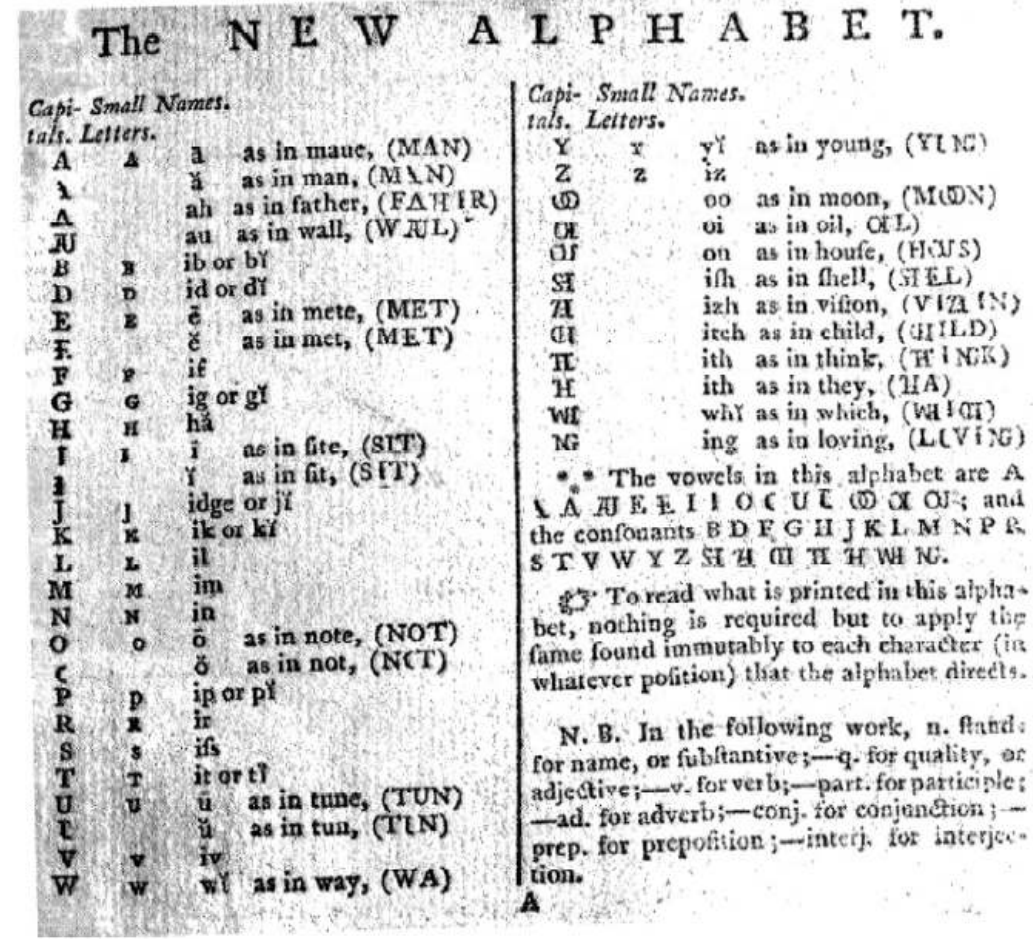

Spence's 'New Alphabet' (1775 : Sig C1, Verso)

It is clear from the statement highlighted by the index finger symbol on figure 1 that Spence's system is intended to be phonetic in the sense that one symbol always represents the same sound and each sound is represented by only one symbol. For instance, whereas in conventional English spelling and Received Pronunciation the letter $<0>^{1}$ can represent a short sound as in loss; a diphthongal sound as in lone, a sound identical to the vowel of cup in monk and a sound identical to the vowel of hit in women, in Spence's alphabet the symbol $<0>$ always represents the long vowel in lone ${ }^{2}$. Thus boat is spelt $<\mathrm{BOT}>$; owe is spelt $<\mathrm{O}>$ and toe is spelt $<\mathrm{TO}>$. I have already mentioned (above, paragraph $n^{\circ} 3$ ) Abercrombie’s description of Spence's alphabet as a "genuine, 
scientific, phonetic alphabet" (1948: 27). A close examination of the distribution of pronunciations represented in the Grand Repository, as carried out by Beal (1999) vindicates Abercrombie's judgement. It is notable, for instance that the last two capital forms in Spence's alphabet acknowledge the phonemic status of $/ M /$ and $/ \mathrm{y} /$. Spence provides a clear and consistent account of what he considered "the most proper and agreeable Pronunciation", which is of great use and interest to historical linguists. a stress mark, then respelt in the upper-case forms of the New Alphabet, as can be seen in figure 2, which reproduces the first page of the dictionary proper.

Figure 2

AN ACCURATE

NEW SPELLING and PRONOUNCING

ENGLISH DICTIONARY.

First dictionary page of the Grand Repository.

20

Spence only uses this entirely upper-case system in the Grand Repository. His other works printed in his reformed spelling, such as A Supplement to the History of Robinson Crusoe (1782) use a script in which capitalisation is used according to the conventions of the time and the lower-case letters are distinguished by diacritics or used in combinations to achieve the phonetic representation. This system is illustrated in figure 3, which reproduces an extract from The Universal Jubilee, a song printed at the beginning of this work. 


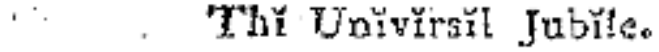 'On redurg thi Hliftire ov Krizonea, trfârk! hou thì Trümpit's Sound, * Proklaınz thr Würld around Thi Juble! Têlz aul thy Poor óprếs'd, No mor tha fhăl be fers'd, Nör Lănetlorda mor molęt "Thar Pröplrte!}

Extract from A Supplement to the History of Robinson Crusoe printed in Spence's alphabet (1782:8). unique. New alphabets had been proposed by spelling reformers and shorthand writers of the $16^{\text {th }}$ and $17^{\text {th }}$ centuries, and, as Beal (1999: 86-7) points out, some of Spence's characters can be found in their works, the system as a whole is his invention. It is based on the conventional alphabet, but expands this by, in the upper-case version, cutting letters in half, using cross-strokes and ligaturing. In figure 1, the alphabet is laid out in conventional alphabetical order (though Spence was ahead of most of his contemporaries in treating $<\mathrm{i}>$ and $<\mathrm{j}>,<\mathrm{u}>$ and $<\mathrm{v}>$ as separate letters, here and in the dictionary), so the four sounds represented in traditional orthography by <a> come first. The capital $<\mathrm{A}>$ as in mane comes first, because it represents the sound identical to the name of the letter; the half-capital is used for the short vowel of man; the capital without the cross-stroke for the long vowel of father; and a ligature of $<A>$ and $<U>$ for the rounded vowel often spelt with <au> in conventional orthography (caul, maul etc.), here exemplified by wall. Although it augments the Roman alphabet, Spence's system does not stray too far from it. Spence claims as much in the preface to A Supplement to the History of Robinson Crusoe: "Nŏthĭng wĭl be mor eze thăn too lĭn too rit ĭn thĭs

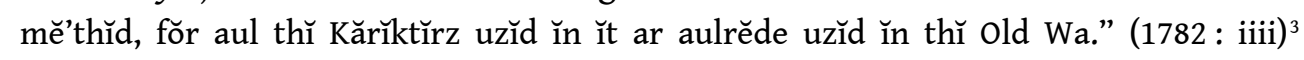
Having spent many years working with Spence's alphabets, I can testify that it is, indeed, easy to learn, though much less easy to reproduce with a conventional keyboard. Spence had the advantage of friendship with the engraver Thomas Bewick, who cut the punches for the Grand Repository. However, as we shall see in the next section Spence's plan for spelling reform was not well received by his contemporaries.

Miranda, 13 | 2016 


\section{Reactions to Spence's spelling}

Rudkin's claim (cited above paragraph $\mathrm{n}^{\circ} 2$ ) that Spence made little use of his reformed spelling after he moved to London is easily refuted. We know that Spence was in London by 1792 because in that year he was imprisoned for selling Thomas Paine's The Rights of Man in London. Spence chose to publish his account of his trial in 1803 firstly in his reformed spelling, as Dhĕ Imporrtănt Triăl ŏv Tŏmı̌s Spěns (1803) and also published Dhĕ Kŏnstĭtushŭn ŏv Spěnsoniă in the same volume. Although we do not know the date of publication of The Pronouncing and Foreigners' Bible, which transliterated the Bible into Spence's script, proof pages of this work in the MS of Francis Place's unpublished biography of Spence, state that it was printed in London. Ashraf concludes that "Spence evidently attempted to launch his phonetic Bible in London" (1983: 152). It is clear from this record of publication in the new alphabet, and from the article in The Giant Killer (1814, cited above paragraph $\left.\mathrm{n}^{\circ} 10\right)$, that, right up to the end of his life, Spence viewed reform of language as integral to his proposed reform of society. However, even those who sympathised with Spence's political ideas saw no merit in his plan for spelling reform. A letter to Spence from Charles Hall, whose ideas on social reform chimed with Spence's makes this clear :

I cannot conceive what should induce you to disguise your work with such a whimsical kind of Spelling, which renders it so difficult to read, that I could more easily read a book in four or five dead or foreign languages, than I could read yours in my native tongue. You say that it is not formed from mere vulgar and uncertain sound, but is systematic. But to acquire a system so as to use it readily requires too much time, for the reading a single work. (Place Add. Ms. 27, 808:22, cited in Shields $1974: 39$ )

Francis Place solicited information about Spence for his planned biography. One letter refers disparagingly to Spence's efforts at spelling reform :

During the whole of his life, he was zealously engaged in propagating his plan of parochial partnership in land. He also published some works in what he termed the Spensonian dialect, being an attempt to render the orthography of the English language identical with its pronunciation, like the Italian. This orthography was somewhat defective, as he spelled the words according to the Northumbrian idiom, Newcastle-on-Tyne being his birthplace.

(Place, BM Add. Ms. 27,808:227, cited in Shields $1974: 39$ )

Another letter makes the same point, whilst referring only to Dhĕ Importănt Triăl ŏv Tŏmı̌s Spěns :

Spence [...] published a curious work, being an attempt to establish a perfect orthography of the English language - in which he gave a second version of his trial for sedition before Lord Ellenborough. He founded his orthography on the same principle as the Italian language, but spelling many sounds according to his native idiom, so his work was anything but classically correct. (Place, BM Add. Ms. 27,808 : 229, cited in Shields $1974: 39$ )

The faults perceived in Spence's spelling reform were thus twofold: it was too much trouble to learn it and the pronunciations represented were not, as Spence had claimed, "the most proper and agreeable", but had been infected by his "Northumbrian idiom".

The claim that Spence's reformed spelling was too difficult to learn is one that had been used before as an argument against spelling reform. John Hart, playing devil's advocate in rehearsing the likely objections to his new orthography, writes : 
[t]hat which use by little and little and with long continuance bringeth into any peoples manner of doings, is never spoken or written against without great offence to the multitude: which will be ten folde more stiffenecked to receive any new letters, than a team of wild Steeres would be at first to receive the bearing of their yokes. Though thexperience should prove it to be verye beneficiall to their posteritie, so much they are offended at all innovations. (1569:11-12, spelling and punctuation in original)

The Anglophone world has proved very resistant to spelling reform: even Noah Webster's reforms, facilitated by the desire to differentiate American English from British English in the wake of Independence, are piecemeal and a long way from the radical systems proposed by Hart and Spence. The eighteenth century was a particularly hostile period for spelling reformers: as noted above (paragraph $\mathrm{n}^{\circ} 13$ ), Johnson's view of the primacy of conventional spelling prevailed. Beal (2002) gives an account of the small cluster of late $18^{\text {th }}$-century spelling reformers and the reception they had. The conclusion is :

So the schemes for reformed spelling put forward in the later eighteenth century were judged to be whimsical, curious, fantastic, absurd and queer, a set of adjectives which describe their referents as outside the mainstream, impractical and not to be taken seriously. (2002:12)

The comment made by Place's correspondents that Spence, as a native of Newcastle, was unable to provide an account of what was then considered correct pronunciation, is similar to criticisms launched against much more successful authors at the time. Thomas Sheridan was a highly successful elocutionist, but his General Dictionary was widely criticised for its alleged Irishisms. On being told of Sheridan's plans for this pronouncing dictionary, Samuel Johnson quipped "what entitles Sheridan to fix the pronunciation of English? He has in the first place the disadvantage of being an Irishman." (Boswell 1934, ii : 161) Welford relates an anecdote which Shields (1974: 50) identifies as "apparently told first by Mackenzie (1827) in which Spence encountered such a criticism and rebuffed it in a typically robust manner.

When soliciting subscriptions to this curious work [The Grand Repository] he called upon the Rev. H. Moises, master of the Grammar- School, morning lecturer of All Saints' Church, for the purpose of requesting him to become a subscriber to the work. As Mr. Spence had a strong Northern accent, Mr. Moises enquired what opportunities he had had of acquiring a just knowledge of the pronunciation of the English Language. "Pardon me," said Spence, "I attend All Saints' Church every Sunday Morning!" (Welford 1895 : 432-3)

In fact, a thorough analysis of the pronunciations represented in the Grand Repository as presented in Beal (1999) leads to the conclusion that, far from spelling his words "according to the Northumbrian idiom", as Place's correspondent suggested, such northernisms as Spence's respellings reveal were not extreme dialectal forms, but those present in what we might call the 'modified standard' of educated and respected citizens. An example of this would be the use of the same vowel in words such as put and cup, already recognised as a northernism in 1775 , but then as now a persistent feature of educated northern usage. Shields likewise demonstrates that such "northern features" as can be found in Spence's spellings "are neither large, nor easily perceived" (1974: 51). I would therefore argue that contemporary criticisms of Spence's plan for spelling reform are easily refuted: his alphabet is relatively easy to use, and his Northumbrian accent is not reflected in the pronunciations represented, but they are typical of arguments against spelling reform in all periods. The final section returns to the link between Spence's two plans and tentatively puts forward the idea that 
objections to his plan for spelling reform, as to his plan for social reform, might be politically motivated.

\section{A radical plan?}

31 The previous section has demonstrated that there was a great deal of opposition to Spence's plan for spelling reform, even from those who were sympathetic to his ideas on social reform. This in itself is not surprising : as Frith notes "[S]pelling reform seems to be subject to fashion to an extraordinary degree and dependant on powerful personalities who occasionally take up its cause" (1980:1) and any departure from conventional orthography was certainly unfashionable in $18^{\text {th }}$-century Britain. Whilst Spence was by all accounts quite a powerful personality, he lacked the influence and the friends in high places needed for such a radical plan to succeed. Quite apart from the practical obstacles to the successful implementation of spelling reform, Spence's plan may have also been too radical in the political sense to have had any chance of success.

The first thing to consider in this regard is Spence's reputation. The Grand Repository was published in Newcastle in the same year that Spence was expelled from the Newcastle Philosophical Society. Officially, this was for breaking the Society's rules by selling the text of his lecture to the Society, Property in Land Every One's Right in the streets, but a contemporary account in the Newcastle Chronicle claims that members of the Society "disclaim all patronage" of the lecture, having been "informed that he [...] became a member, apparently, for the purpose of obtruding upon the world, the ERRONEOUS and dangerous levelling principles, with which the lecture is replete" $\left(25^{\text {th }}\right.$ November 1775, capitalisation in original) In London, Spence came to the attention of much more powerful authorities than the Newcastle Philosophical Society, and proved too radical even for the London Corresponding Society. Bindman notes that, Spence "was on the radical wing of the LCS ; a 'violent democrat', in the words of an informer, with 'levelling' tendencies that worried the more moderate executive" (1989: 56). Spence was arrested three times, and was subject to surveillance by the government. Ashraf tells us that "the Home Secretary drew the attention of the police to sayings like 'Spence's Plan and Full Bellies' which had appeared on every wall in London” (1983 : 87).

In Spence's view, spelling reform was an instrument for levelling, as can be seen from the extract from A Supplement to the History of Robinson Crusoe cited above (paragraph $\left.\mathrm{n}^{\circ} 15\right)$. Quite apart from the fact that Spence and his political ideas were viewed as dangerous, his ideas on spelling reform, which are viewed by later scholars as an eccentricity, would, in the late $18^{\text {th }}$ century, be viewed as equally revolutionary. Spence intended his reformed spelling primarily for what he termed "the laborious part of the people, who generally cannot afford much time or expence [sic] in the educating of their children" (1775 : Sig B2 Recto). As an autodidact, Spence viewed education as the key to liberation, and spelling reform as the key to education for those without the means for schooling. It is possible that Spence's vision of a liberated and therefore rebellious proletariat was shared by his opponents. Hannah More, otherwise an advocate of education, was, according to her biographer Skedd "adamant that the poor should not be taught writing, as it would encourage them to be dissatisfied with their 
lowly situation" (2004). Dissatisfaction with their "lowly situation" was, of course, exactly what Spence intended for "the laborious part of the people".

In Spence's view, and in that of his opponents, language, or at least literacy, was inextricably linked with politics : his plan for reform of society and his plan for spelling reform were both essential parts of "Spence's Plan" which promised "Full Bellies" to the citizens of London, to the alarm of the home secretary. He was not the only one, or the last, to make this link between language and politics. William Cobbett, who attended Spence's trial in 1801, wrote that "tyranny has no enemy so formidable as the pen" (1823:4) and the potential power of language is recognised by all political factions. The last word goes to Foucault, who describes exactly the procedures that Spence sought to subvert :

\section{BIBLIOGRAPHY}

In every society the production of discourse is at once controlled, selected, organised and redistributed according to a certain number of procedures, whose role is to avert its powers and dangers. (1972: 216)

Abercrombie, David. "Forgotten Phoneticians." Transactions of the Philological Society 47 (1948) : $1-35$.

---. Studies in Phonetics and Linguistics. London : Oxford University Press, 1965.

Alston, Robin C. A Bibliography of the English Language from the Invention of Printing to the Year 1800. Volume I : English Grammars Written in English. Leeds : E.J. Arnold and Son.

Ashraf, P. Mary. The Life and Times of Thomas Spence. Newcastle : Frank Graham, 1983.

Beal, Joan C. English Pronunciation in the Eighteenth Century: Thomas Spence's 'Grand Repository of the English Language'. Oxford : Clarendon Press, 1999.

---. “'Out in Left Field' : Spelling Reformers of the Eighteenth Century." Transactions of the Philological Society 100 (2002) : 5-23.

---. English in Modern Times. London : Arnold, 2004.

---. "The example of the French : the influence of French normative ideas on the codification of the English Language." In Langue Commune et Changements de Normes. Ed. Sonia Branca-Rosoff, Jean-Marie Fournier, Yana Grinshpun and Anne Régent-Susini. Paris : Champion, 2011. 435-446.

Bindman, David. The Shadow of the Guillotine : Britain and the French Revolution. London : British Museum Publications, 1989.

Boswell, James. Ed. G. Birkbeck Hill. Life of Johnson. Oxford : Clarendon Press, 1934.

Buchanan, James. Linguae Britannicae Vera Pronunciatio. London : A. Millar, 1757.

Dickinson, Harold T. "Spence, Thomas (1750-1814)" Oxford Dictionary of National Biography. Site visited 24 June 2015.

<http://www.oxforddnb.com/view/article/26112>. 
Finegan, Edward. "English grammar and usage." In The Cambridge History of the English Language. vol. IV. Ed. Suzanne Romaine. Cambridge : Cambridge University Press, 1998. 536-588.

Foucault, Michel. The Archaeology of Knowledge and the Discourse on Language. London : Tavistock, 1972.

Frith, Uta. Cognitive Processes in Spelling. New York : Academic Press, 1980.

Hart, John. An Orthographie. London : Seres.

Haugen, Einar. "The ecology of language." The Linguistic Reporter supplement 25 (winter 1971) : 19-26.

Holmberg, Borje. On the Concept of Standard English and the History of Modern English Pronunciation. Lund : Gleerup, 1964.

Johnson, Samuel. A Dictionary of the English Language. London : W. Strahan.

OED online. "ascertain, v." OED Online. Oxford University Press, June 2015. Site visited 25 June 2015. <www.oed.com>.

Jones, Charles. English Pronunciation in the Eighteenth and Nineteenth Centuries. Basingstoke :

Palgrave Macmillan, 2006.

Jones John. Practical Phonography. London : Richard Smith 1701.

Mackenzie, Eneas. A Descriptive and Historical Account of the Town and County of Newcastle upon Tyne. Newcastle : Mackenzie and Dent, 1827.

Place, Francis. Unpublished Mss. London : British Museum.

Puttenham, George. The Art of English Poesie. London : R. Field, 1589.

Rudkin, Olive D. Thomas Spence and His Connections. London : G. Allen \& Unwin, 1927.

Sheridan, Thomas. A Dissertation on the Causes of the Difficulties which Occur, in Learning the English Tongue. London : R. and J. Dodsley, 1762.

---. A General Dictionary of the English Language. London : R. \& J. Dodsley, C. Dilly and J. Wilkie, 1780.

Shields, Anthea Fraser. "Thomas Spence and the English Language.” Transactions of the Philological Society 73 (1974) : 33-64.

Skedd, S. J. "More, Hannah (1745-1833)", Oxford Dictionary of National Biography. Site visited $2^{\text {nd }}$ July 2015. http://www.oxforddnb.com/view/article/19179.

Spence, Thomas. The Grand Repository of the English Language. Newcastle : Thomas Saint, 1775.

---. Property in Land is Every One's Right. Newcastle : the Author, 1775.

---. A Supplement to the History of Robinson Crusoe. Newcastle : Thomas Saint, 1782.

---. The Giant-killer, or Anti-landlord. London : the Author, 1814.

Swift, Jonathan. A Proposal for Correcting, Improving and Ascertaining the English Tongue. London : Benjamin Tooke, 1712 .

Tedder, H. R. "Spence, Thomas (1750-1814)" Oxford Dictionary of National Biography Archive. Site visited $24^{\text {th }}$ June 2015.

<http://www.oxforddnb.com.eresources.shef.ac.uk/view/olddnb/26112>. 
Tieken-Boon van Ostade, Ingrid. "Grammars, grammarians and grammar writing : An introduction". In Grammars, Grammarians and Grammar-Writing in Eighteenth-Century England. Ed. Ingrid Tieken Boon van Ostade. Berlin : Mouton de Gruyter, 2008. 1-14.

Trapateau, Nicolas “"'Pedantick", "Polite” or "Vulgar" ? A systematic analysis of eighteenthcentury normative discourse on pronunciation in John Walker's dictionary (1791)" Language and History $59: 1$ (2016) :

Walker, John. A Critical Pronouncing Dictionary. London : G.G.J. and J. Robinson and T. Cadell, 1791.

Welford, Richard. Men of Mark ‘Twixt Tyne and Tweed. Newcastle : Walter Scott, 1895.

\section{NOTES}

1. Here I am using the convention of angled brackets to represent spelling forms. This is the usual convention in linguistics to distinguish spellings from pronunciations, the latter being placed between slashes / / or square brackets [ ].

2. In $18^{\text {th }}$-century English, this vowel was pronounced as pure long vowel like the French word haut. The diphthongal pronunciation of present-day Received Pronunciation was a later development.

3. "Nothing will be more easy than to learn to write in this Method, for all the characters used in it are already used in the old Way". I have in this instance cited the Crusonean version in order to prove Spence's point to the reader.

\section{ABSTRACTS}

This article discusses Thomas Spence's scheme of reformed spelling and its place within Spence's broader plan for the reform of society. Whilst earlier commentators on and biographers of Spence tended to dismiss his ideas on language as trivial or even misguided, more recent scholarship recognises the interconnection of language and politics in Spence's radical plan. This article sets Spence's linguistic ideas within the context of $18^{\text {th }}$-century prescriptivism and standardisation of language, arguing that, although Spence is prescriptive in advocating the adoption of "correct" pronunciation, his plans for spelling reform are in direct opposition to the prevailing trends of the time. Spence's ideas on spelling reform both hark back to those of $16^{\text {th }}$ century reformers (e.g. Hart), and anticipate $20^{\text {th }}$-century schemes such as the Initial Teaching Alphabet, but his scheme for implementing them is unique. Finally, the article resumes its discussion of the interconnectedness of language and politics, setting Spence's ideas alongside those of later scholars and activists such as Cobbett and Foucault.

Cet article se penche sur le projet de réforme orthographique de Thomas Spence et sur la façon dont il s'inscrit dans le cadre de son projet politique de transformation de la société. Alors que les spécialistes de Spence (y compris ses biographes) ont eu tendance à reléguer les idées qu'il a formulées sur le langage à l'arrière-plan, au motif qu'elles étaient au mieux insignifiantes ou au pire erronées, des études plus récentes reconnaissent les liens entre langage et politique dans le projet radical de Spence. Cet article replace les idées linguistiques de Spence dans le contexte du 
prescriptivisme typique du $18^{\text {ème }}$ siècle et de la standardisation de la langue qu'il imposait. Il affirme que, même si Spence se montre prescriptif lorsqu'il défend la mise en place d'une prononciation «exacte", son projet pour la réforme des normes orthographiques s'oppose frontalement aux tendances de fond de l'époque. Ses idées concernant la réforme de l'orthographe font appel aux réformateurs de $16^{\text {ème }}$ siècle comme Hart, mais anticipent également les propositions du $20^{\mathrm{ème}}$ siècle comme celle contenue dans le Initial Teaching Alphabet. Le projet de Spence se révèle cependant unique. En dernier lieu, cet article reprend le débat du lien entre langage et politique en mettant les idées de Spence en perspectives avec celles de militants ou d'universitaires d'époques ultérieures comme Cobbett et Foucault.

INDEX

Keywords: spelling reform, prescriptivism, language and politics

Mots-clés: rénovation de l'orthographe, préscriptivisme, langage et politique

\section{AUTHORS}

JOAN BEAL

Professor

University of Sheffield 